\title{
Inquiry of the relationship between the popularity of foreign languages and the learning effectiveness on the basis of OKM 2016 database
}

\author{
ZITA SOMFALVI* \\ University of Debrecen, Doctoral Program on Educational Sciences, Debrecen, Hungary
}

\section{RESEARCH ARTICLE}

Published online: June 16, 2020

(C) The Author(s) 2020

\begin{abstract}
This study's objective is to determine the relationship between the popularity of the foreign language and the study efficiency based on the OKM 2016 database. In our results you can see that the popularity of foreign languages is outstanding compared to other subjects. Concerning the gender and study average it is apparent that among girls and those with higher study average the subject is more popular than among boys and those with lower study average. The results of regression show that girls, those who live in town, who attend high school, who learn in larger schools, who do not attend religious school, who are descendants of highly educated parents and those whose parents' status is active in the labour market have positive opinion. Beyond the socio-demographic variables the popularity of the foreign language as a subject has an effect on the study average. The relevance of this study can be defined in the future research of unsuccessful language learning.
\end{abstract}

\section{KEYWORDS}

popularity of foreign languages, study efficiency, language learning

\section{INTRODUCTION}

Foreign language teaching in Hungary has been in the centre of interest for a long time. In today's Hungarian education system, foreign language teaching plays a key role in its

*Corresponding author. E-mail: z.somfalvi@gmail.com 
multidimensional utilization. It has significance in the acquisition of a degree, in labour market opportunities and in all aspects of intellectual life. Although many studies have already examined the conditions of language teaching and learning, their processes and results (including Csapó, 2001; Fekete, Major, \& Nikolov, 1999; Hwang et al., 2017; Józsa, \& Nikolov, 2005), we still cannot say we have enough knowledge of what is happening in foreign language lessons. However, the degree to which students like the learnt foreign language is likely to affect their learning outcomes.

Based on OKM 2016 database, our study examines the relationship between the popularity of foreign languages and the learning effectiveness in order to demonstrate a relationship between these two factors. Foreign language competences are measured as a part of The National Competency Measurement (in the followings OKM) and it is held among those students of 6th and 8th grade $(N=88,382)$ who learn English or German as the first foreign language. We use the methodology of cross-table and variance analysis, cluster groups, logistic and linear regression models to study the factors of the popularity of foreign languages.

\section{THE EFFECTIVENESS OF FOREIGN LANGUAGE EDUCATION IN HUNGARY}

Numerous researches have been carried out to find out how effective the development of foreign language skills is in Hungarian public education. To be able to look at the effectiveness we need to know what level of knowledge we mean. For this, the level of language proficiency required by the National Core Curriculum and Framework Curricula is relevant. In order to measure the acquisition of language competences, the inquiry of the four basic skills (listening comprehension, speaking, reading, writing) is required (Nikolov \& Vígh, 2012).

According to the survey conducted by the Ministry of Education between 2001 and 2003 at the National Institute of Public Education, the most frequently mentioned problems of teachers in both primary and secondary education were the lack of time, high number of students, lack of interest and lack of motivation (Nikolov \& Vígh, 2012).

Csapó's (2001) survey reveal that the problems indicated by language teachers and the results of students reflect the difficulty of high school teachers being dissatisfied with the knowledge and motivation of those arriving from primary school (Nikolov \& Vígh, 2012).

Despite the fact that in the last decade students had an equal share of English and German language teaching both in primary and secondary education, it can be seen that English is gaining ground in schools. From the Eurostat surveys, we can see that the English language is chosen much more than German. The reason for this is that the globalization of the English language gradually overcomes other European languages (Nikolov \& Vígh, 2012). It is also worth mentioning how the social background influences the choice of foreign language in our country. According to Csapó (2001), the higher the parents' education level, the more likely it is that they choose English as the first foreign language, while children with less educated parents are more likely to choose German. Language policy does not restrict the choice; the first foreign language is not regulated in our country. However, according to a survey conducted in the European Union in 2005, in ten member states out of the 23 English was obliged to elect (Nikolov \& Vígh, 2012).

Comparing Hungarian and international public education, Vágó (2007) finds that in Hungary there is a very high number of foreign language lessons and the proportion of language teachers is also higher than in other countries. In an average grammar school students have 
1,363 foreign language lessons, in technical schools they have 1,240 and in vocational schools they have 711. Nevertheless, the effectiveness of Hungarian foreign language teaching is quite low compared to the level of expenditures. Individual learning outcomes cannot be treated irrespective of parents' educational background, type of school, learning motivation, attitudes, and background variables in students' milieu.

According to the 2015 survey of the Education First Proficiency Index, Hungary is ranked 21 st in seventy countries in terms of language proficiency and nearly $59 \%$ speak at least one foreign language. We can think that this rate is low, but if we have a look at the world rankings, this score is average. Yet, it may be surprising if we consider the low number of university degrees handed out in lack of foreign language exam. So the question arises where the problem is rooted. We cannot say that we start to learn it too late, since in most primary schools parents can choose foreign language learning for their children in the first year of school. However, it is arguable that teachers choose the right method to make both skills and pragmatics acquired (Balázs, Kocsis, \& Vágó, 2010).

There are several problems in current language teaching. Regarding the framework of language teaching in public education, we would not assume that it is not effective: the number of lessons is relatively high, curricula are available to the instructors and the qualifications of the teachers seem appropriate. By contrast, language learning starting from the age of 9 or 10 faces international trends, and the number of public institutions where students can learn a foreign language from the first year is relatively low. However, these classes are not supported by central teaching materials, so foreign language teaching does not necessarily work properly. So the way of students' language learning can differ in this period, which will result in greater distance among students due to the pace of progress and the efficiency of education. It is also a problem that the output levels given in the content policies are not based on empirical data; therefore their performance cannot be measured. For the elevated output level of the 8th grade of the National Fund Curriculum, data from the real level can only be obtained from foreign language measurements made in 2015. Although language teachers are trained, it can still be stated that language teaching in accordance with current regulations (which means that a language teacher with language teacher qualifications can teach in nearly all school types) is not necessarily effective. Language teaching in the lower primary school does not require the same methodological preparation as in high school (Csejk, 2017).

\section{METHODOLOGY}

The National Competency Measurement (in the followings referred to as "OKM") examines reading comprehension and mathematical skills of students of grades 6,8 and 10 defined in the policy on public education. The first competence measurement was 2001, but the first foreign language test was conducted on 11th June 2015, based on the 35/2014 (IV. 30.) EMMI regulation. Foreign language measurement is held among those students of 6th and 8th grade who learn English or German as the first foreign language.

Prior to our empirical research based on the OKM 2016 database, we have set the following hypotheses:

1. The popularity of the foreign language among students is remarkably good. (Csapó, 2000)

2. Girls are more positive about foreign language learning than boys (Csizér \& Dörnyei, 2002) 
3. Students above the average prefer foreign language more than students below the average. (Imre, 1999; Nikolov \& Vígh, 2012)

4. Depending on the popularity of the subjects, students can be divided into three groups: humanities, sciences and art lovers. It is assumed that lovers of foreign language belong to the group of humanities. (Nikolov \& Vígh, 2012)

5. It is assumed that certain social-demographic variables (gender, type of settlement, parents' qualifications and parents' labour market status), type and maintainer of the school influence the popularity of the foreign language. Primarily those with a better socio-demographic background, those attending grammar school and students in the ecclesiastical school love the foreign language. (Csapó, 2001)

6. It is assumed that the grade point average is influenced by the popularity of the foreign language, the socio-demographic background variables (gender, type of settlement, parents' qualifications and parents' labour market status), the type and maintainer of the school. So foreign language lovers have a better grade point average, have better socio-demographic backgrounds, go to grammar school and learn in ecclesiastical institution. (Nikolov \& Vígh, 2012)

\section{RESULTS}

\section{Popularity of the subjects}

First of all, we are examining how much the students participating in the National Competency Measurement like each subject (Fig. 1).

Based on the first diagram we can say that the foreign language subject is on the second place in the rankings of subjects, so our first hypothesis seems to be verified. Students preferred the foreign language preference on the Likert scale ranging to an average of 3.67 , which was

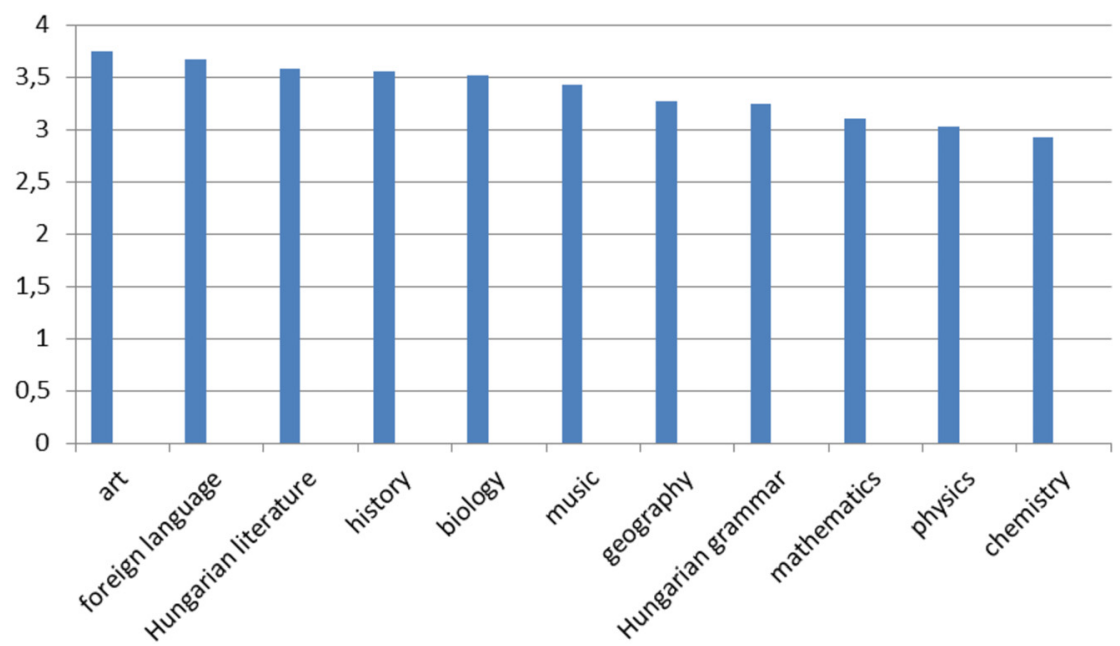

Figure 1. Popularity of the subjects on 1-5 Likert scale $(N=88,382)$, Source: OKM 2016 
preceded only by art (3.75). Data show that foreign language is followed by humanities such as literature (3.58) and history (3.55). Biology seems to be the most popular (3.52) of the science subjects. Among the art subjects, music is in the midfield (3.42). In the second half of the rankings science subjects are lined up (although the Hungarian grammar is also there with 3.25), such as geography (3.27), mathematics (3.11), physics (3.03) and chemistry (2.92).

\section{Popularity of foreign language}

In the followings we examine the popularity of foreign languages by sex, which is examined with the following variables:

The extent to which they love the foreign language is divided into two groups: we have created a love foreign language item from the love and like items, while the indifferent and the dislike items has been classified in the dislike foreign language category. The results are shown in the following table (Table 1):

The result of cross-table analysis shows that there is a significant correlation $(P=0.000)$ between the popularity of the foreign language and the sex variables. It can be seen that $53 \%$ of girls prefer foreign language, while $47 \%$ of boys think positively about the subject. In addition, $47.5 \%$ of girls and $52.5 \%$ of boys reported negatively on foreign language. So our second hypothesis has been confirmed that girls are more positive about learning a foreign language than boys.

\section{The relationship between the grade point average and the popularity of foreign language}

In this part we will examine the correlation between the grade point average and the popularity of foreign language (Table 2).

The results of the variance analysis show that students had a grade point average of 4 in general. There is a significant correlation $(P=0.000)$ between the study average and the popularity of foreign language. In Table 2 we can say that students who love the foreign language have a higher grade point average (4.2) than those who do not like this subject (3.7). Our hypothesis has been confirmed that students above the average prefer foreign language more than those with a poorer average.

Table 1 . The popularity of foreign language by gender $(N=69,639)(P=0.000)$

\begin{tabular}{llcc}
\hline & & Dislike foreign language & $\begin{array}{c}\text { Like foreign } \\
\text { language }\end{array}$ \\
\hline Girl & $\%$ & 47.5 & 53 \\
& Item number & 12,675 & 22,739 \\
Boy & $\%$ & 52.5 & 47 \\
& Item number & 14,032 & 20,193 \\
& $\%$ & 100 & 100 \\
& Item number & 26,707 & 42,932 \\
\hline
\end{tabular}

Source: OKM 2016. 
Table 2. Context of foreign language and grade point average $(N=58,292)(P=0.000)$

\begin{tabular}{llc}
\hline & & Grade point average of the last term \\
\hline Like foreign language & Average & 4.191 \\
& Item number & 36,782 \\
Dislike foreign language & Average & 3.6999 \\
& Item number & 21,510 \\
All & Average & 4.010 \\
& Item number & 58,292 \\
Anova & & 0.000 \\
\hline
\end{tabular}

Source: OKM 2016.

\section{Grouping of students based on the popularity of subjects}

In the following we examine how the students who like the enrolled 11 subjects are grouped according to the popularity of the subjects. We assumed that three groups of students would develop: people who like humanities, sciences and art subjects. We also assumed that those who love a foreign language belong to the group of people who like humanities. The results are shown in Table 3.

The results of the cluster analysis show that our preliminary hypothesis has not been confirmed, that there are three cluster groups. In our study, we adopted a four-cluster solution to form a group of people who like humanities (since high scores have been given to literature, Hungarian grammar and history), a group of lovers of all subjects, a group of lovers of arts and all except for those who do not like science objects. The data show that lovers of foreign language belong to the group of people who like humanities and those who like everything (since both places were rated 4 on the Likert scale). Most of the students interviewed were in the group

Table 3. Cluster groups of the popularity of the subjects $(N=64,505)$ Values over 3,5 are in bold

\begin{tabular}{lcccc}
\hline & $\begin{array}{c}\text { Those who like } \\
\text { humanities }\end{array}$ & $\begin{array}{c}\text { Those who like } \\
\text { all }\end{array}$ & $\begin{array}{c}\text { Those who like } \\
\text { arts }\end{array}$ & $\begin{array}{c}\text { Those who dislike } \\
\text { sciences }\end{array}$ \\
\hline $\begin{array}{l}\text { Hungarian } \\
\text { grammar }\end{array}$ & $\mathbf{3 . 5 0}$ & $\mathbf{3 . 6 6}$ & 2.97 & 2.53 \\
$\begin{array}{l}\text { Hungarian } \\
\text { literature }\end{array}$ & $\mathbf{3 . 9 9}$ & $\mathbf{3 . 9 9}$ & 3.19 & 2.78 \\
Mathematics & & & & \\
History & 2.36 & $\mathbf{3 . 8 7}$ & 3.28 & 2.60 \\
Biology & $\mathbf{3 . 7 9}$ & $\mathbf{4 . 1 7}$ & 2.89 & 3.07 \\
Chemistry & 3.45 & $\mathbf{4 . 0 4}$ & 3.43 & 2.78 \\
Physics & 2.30 & $\mathbf{3 . 7 6}$ & 2.98 & 2.21 \\
Geography & 2.31 & $\mathbf{3 . 8 5}$ & 3.13 & 2.47 \\
Music & 3.20 & $\mathbf{3 . 8 5}$ & 3.02 & 2.63 \\
Art & $\mathbf{3 . 6 0}$ & $\mathbf{3 . 6 9}$ & $\mathbf{3 . 6 8}$ & 2.19 \\
Foreign & $\mathbf{3 . 9 5}$ & $\mathbf{3 . 9 6}$ & $\mathbf{4 . 0 6}$ & 2.57 \\
$\quad$ language & $\mathbf{4 . 0 1}$ & $\mathbf{4 . 2 2}$ & 3.05 & 3.09 \\
All (person) & & & & 10,596 \\
\hline
\end{tabular}

Source: OKM 2016. 
of people who liked everything $(20,632)$, while the fewest were in the group of those who do not like science subjects $(10,596)$.

\section{Examining clusters by gender}

Although in our study we have previously examined the popularity of foreign language by gender variable and our hypothesis has been confirmed, we will also examine the clusters by gender (Table 4).

The results of the variance analysis show that there is a significant correlation between cluster groups and the gender variable. Among those who like humanities there are more girls (66.1\%), among those who like all subjects there are more boys (53.4\%), among those who like arts there are more girls (51.6\%), while among those who like science subjects there are more boys (64.8\%).

\section{Influence of socio-demographic variables on the popularity of foreign languages}

Our fifth hypothesis is examined with a logistic regression model. We assume that socio-demographic variables (gender, type of settlement, educational attainment of parents, labour market status of parents), the type and maintainer of the school influence the popularity of the foreign language. Our hypothesis is that those with a better socio-demographic background, those attending grammar school and those in a church institution will love the foreign language.

The variables were entered gradually. In the first step we included the gender $(0=$ girl, $1=$ boy) variable and the settlement type $(0=$ village, $1=$ city). It can be seen that girls and those living in the city were significantly more positive about the foreign language.

In the second step, besides the type of gender and settlement we also included the type of school $(0=$ non-high school, $1=$ high school $)$, the size of the school $(0=$ small, $1=$ large $)$ and the type of maintenance $(0=$ non-church, $1=$ church $)$. The table shows that by entering the type, size and maintenance of the school the gender variable became stronger, while the type of settlement weakened. Pupils in high school, in larger school, and students in a nonecclesiastical institution were more positive about foreign language than non-high school students, those attending a small school and those in a church-maintained institution (Tables 5 and 6).

Table 4. Cluster by gender $(N=64,505)(P=0.000)$

\begin{tabular}{llcccc}
\hline & & $\begin{array}{c}\text { Those who like } \\
\text { humanities }\end{array}$ & $\begin{array}{c}\text { Those who } \\
\text { like all }\end{array}$ & $\begin{array}{c}\text { Those who } \\
\text { like arts }\end{array}$ & $\begin{array}{c}\text { Those who } \\
\text { dislike } \\
\text { sciences }\end{array}$ \\
\hline Girl & $\%$ & 66.1 & 46.6 & 51.6 & 35.2 \\
& item number & 11,033 & 9,606 & 8,565 & 3,728 \\
Boy & $\%$ & 33.9 & 53.4 & 48.4 & 64.8 \\
& All & 5,658 & 11,026 & 8,021 & 6,868 \\
& item number & 100 & 100 & 100 & 100 \\
& item number & 16,691 & 20,632 & 16,586 & 10,596 \\
\hline
\end{tabular}

Source: OKM 2016. 
Table 5. Logistic regression models for the popularity of the foreign language entering the variables gradually $(N=88,382)$

\begin{tabular}{lccc}
\hline Explanatory variable & $\operatorname{Exp}(\mathrm{B})$ & $\operatorname{Exp}(\mathrm{B})$ & $\operatorname{Exp}(\mathrm{B})$ \\
\hline Gender & $0.804^{* * *}$ & $0.810^{* * *}$ & $0.791^{* * *}$ \\
Type of settlement & $1.727^{* * *}$ & $1.491^{\star * *}$ & $1.256^{* * *}$ \\
Type of school & & $2.038^{* * *}$ & $1.537^{* * *}$ \\
Size of school & & $1.220^{\star * *}$ & $1.096^{* *}$ \\
Type of maintainer & & $0.953^{*}$ & $0.945^{*}$ \\
Qualification of mother & & & $1.576^{* * *}$ \\
Qualification of father & & & $1.454^{* * *}$ \\
Mother works & & & $1.160^{* * *}$ \\
Father works & 1.24 & 1.89 & $1.175^{* * *}$ \\
RL2 $=$ & & & 4.16 \\
\hline
\end{tabular}

Source: OKM 2016.

Table 6. Linear regression models for grade point average $(N=88,382)$

\begin{tabular}{lrcrc}
\hline Explanatory variable & $\mathrm{B}$ & Std. mistake & Beta & Significancy \\
\hline Constant & 3.323 & 0.012 & & 0.000 \\
Like foreign language subject & 0.331 & 0.006 & 0.212 & 0.000 \\
Type of school & 0.056 & 0.009 & 0.023 & 0.000 \\
Type of settlement & -0.040 & 0.007 & -0.023 & 0.000 \\
Size of school & 0.012 & 0.009 & 0.006 & 0.151 \\
Type of maintainer & 0.036 & 0.008 & 0.017 & 0.000 \\
Gender & -0.292 & 0.005 & -0.194 & 0.000 \\
Qualification of mother & 0.400 & 0.007 & 0.259 & 0.000 \\
Qualification of father & 0.276 & 0.006 & 0.183 & 0.000 \\
Mother works & 0.118 & 0.007 & 0.059 & 0.000 \\
Father works & 0.173 & 0.009 & 0.069 & 0.000 \\
\hline
\end{tabular}

Source: OKM 2016.

In the third step, the parents' education $(0=$ low, $1=$ high $)$ and the parents' labour market status $(0=$ not working, $1=$ working) were included. It can be seen that the strength of the variables involved in the previous stages was weakened. The data show that students whose parents have a higher level of education and are active in the labour market are more likely to prefer a foreign language.

The effects on the grade point average were analysed by linear regression. The following variables were included: whether like the foreign language subject, the type of school, the type of settlement, the size of the school, the type of maintainer, the gender, the qualification of the parents, the labour status of the parents. The results show that the study average depends on the popularity of the foreign language $(P=0.000)$, the type of school $(P=0.000)$, the type of settlement $(P=0.000)$, the type of maintainer $(P=0.000)$, the gender $(P=0.000)$, mother's qualification $(P=0.000)$, father's qualification $(P=0.000)$, mother's labour market status $(P=$ $0.000)$ and father's labour market status $(P=0.000)$. However, the grade point average does not 
depend on the size of the school. The table shows that the better grade point average is influenced by when a student likes a foreign language, goes to grammar school, lives in a village, attends a bigger school, goes to church-maintained school, a girl, her parents are well qualified and employed in the labour market. Our hypothesis has been confirmed, because the grade point average is affected by the popularity of the foreign language, the socio-demographic background, the type of school and its maintainer.

\section{CONCLUSION}

Overall, the popularity of foreign languages among students is excellent compared to the other subjects. Regarding the gender and the grade point average it was apparent that girls and those with a better educational achievement average prefer the foreign language subject than boys and those with a lower grade point average.

Regression results showed that girls, city dwellers, high school students, those who attend bigger schools, non-ecclesiastic students, children of higher educated parents and children of parents with active labour market status were more positive about foreign language.

It was also evident that, apart from socio-demographic variables, the grade point average is influenced by how much the student loves the foreign language as a subject.

Ethics: The study procedures were carried out in accordance with the Declaration of Helsinki. The Institutional Review Board of the Institute of Educational and Cultural Sciences (University of Debrecen) approved the study.

Funding sources: No financial support was received for this study.

Authors' contribution: The author takes responsibility for the integrity of the data and the accuracy of the data analysis.

Conflict of interest: The author declares no conflict of interest.

\section{ACKNOWLEDGEMENTS}

No additional acknowledgement.

\section{ABOUT THE AUTHOR}

Zita Somfalvi is a teacher of English language and methodology at the University of Nyíregyháza, faculty of English language and culture. She is working on her $\mathrm{PhD}$ thesis in the Doctoral School of Human Sciences at the University of Debrecen, in the topic of unsuccessful language learning and drop out. 


\section{REFERENCES}

Balázs É., Kocsis M., \& Vágó I. (szerk.). (2010). Jelentés a magyar közoktatásról. Budapest: Oktatáskutató és Fejlesztő Intézet.

Csapó B. (2000). A tantárgyakkal kapcsolatos attitűdök összefüggései. Magyar Pedagógia, 100(3), 343-366.

Csapó B. (2001). A nyelvtanulást és a nyelvtudást befolyásoló tényezők. Iskolakultúra, 11(8), 25-30.

Csejk M. (2017). Minöségi problémák a hazai nyelvoktatásban. Magyar idők. https://magyaridok.hu/ belfold/minosegi-problemak-hazai-nyelvoktatasban-1973818/ (letöltés ideje: 2018 03.19).

Csizér K., \& Dörnyei Z. (2002). Az általános iskolások idegennyelv-tanulási attitüdjei és motivációja. Magyar Pedagógia, 102(3), 333-353.

Education First Profficiency. https://ef.co.hu/epi (letöltés: 2017 03.02).

Fekete H., Major É., \& Nikolov M. (szerk.). (1999). English language education in Hungary: A baseline study. Budapest: The British Council.

Hwang, A., Wang, J., Józsa, K., Wang, P., Liao, H., \& Morgan, G. A. (2017). Cross cultural invariance and comparisons of Hungarian-, Chinese-, and English-speaking preschool children leading to the revised dimensions of mastery questionnaire (DMQ 18). Hungarian Educational Research Journal, 7(2), 48-67. https://doi.org/10.14413/HERJ/7/2/4.

Imre A. (1999). Az idegennyelv-oktatás kiterjedésének hatása az nemzetiségnyelv-oktatásra. In I. Vágó (szerk.), Tartalmi változások a közoktatásban a 90-es években (pp. 175-202). Budapest: OKIKK Okker Kiadó.

Imre A. (2007). Nyelvoktatás, nyelvtanulás, nyelvtudás a középfokú oktatásban. In I. Vágó (szerk.), Fókuszban a nyelvtanulás (pp. 107-136). Budapest: Oktatáskutató és Fejlesztő Intézet.

Józsa, K., Kis, N., \& Huang, S. (2017). Mastery motivation in school subjects in Hungary and Taiwan. Hungarian Educational Research Journal, 7(2), 158-177. https://doi.org/10.14413/HERJ/7/2/10.

Józsa K., \& Nikolov M. (2005). Az angol és német nyelvi készségek fejlettségét befolyásoló tényezők. Magyar Pedagógia, 3, 307-337.

Nikolov M., \& Vígh T. (2012). Az idegen nyelvek tanulásának eredményessége. In B. Csapó (szerk.), Mérlegen a magyar iskola (pp. 241-188). Budapest: Nemzeti Tankönyvkiadó.

Országos Kompetencia Mérés 2016.

Vágó I. (2007). Nyelvtanulási utak Magyarországon. In I. Vágó (szerk.), Fókuszban a nyelvtanulás (pp. 137174). Budapest: Oktatáskutató és Fejlesztő Intézet.

Open Access statement. This is an open-access article distributed under the terms of the Creative Commons Attribution 4.0 International License (https://creativecommons.org/licenses/by/4.0/), which permits unrestricted use, distribution, and reproduction in any medium, provided the original author and source are credited, a link to the CC is provided, and changes - if any - are indicated. (SID_1) 